\title{
Article \\ Energy Consumption Linkages of the Chinese Construction Sector
}

\author{
Zhaocheng Li and Yu Song *(D) \\ School of Business, Macau University of Science and Technology, Macau 999078, China; \\ 2009853ebm30001@student.must.edu.mo \\ * Correspondence: ysong@must.edu.mo; Tel.: +853-88972350
}

check for updates

Citation: Li, Z.; Song, Y. Energy Consumption Linkages of the

Chinese Construction Sector. Energies 2022, 15, 1761. https://doi.org/

$10.3390 /$ en15051761

Academic Editor: Dimitrios

Katsaprakakis

Received: 5 February 2022

Accepted: 23 February 2022

Published: 26 February 2022

Publisher's Note: MDPI stays neutral with regard to jurisdictional claims in published maps and institutional affiliations.

Copyright: (c) 2022 by the authors. Licensee MDPI, Basel, Switzerland. This article is an open access article distributed under the terms and conditions of the Creative Commons Attribution (CC BY) license (https:/ / creativecommons.org/licenses/by/ $4.0 /)$.

\begin{abstract}
The purpose of this paper is to explore the relationships between the construction sector and the rest of the Chinese economy in the energy consumption as it is crucial in energy consumption of the whole economy. Therefore, this paper uses the Modified Hypothetical Extraction Method (MHEM) to quantify the linkages of energy consumption in 2002, 2005, 2007, 2010, 2012, 2015, 2017 and 2018, providing a new perspective for energy consumption linkage studies in China. In this paper we discover the volumes and paths of energy consumption net flows from other blocks to the construction sector and identify the key energy suppliers of the construction sector. The empirical findings show that the indirect energy consumption exceeded the direct energy consumption between 2002 and 2018, representing more than $90 \%$ of total (direct plus indirect) energy consumption of the construction sector. Between 2002 and 2018, the indirect energy consumption of the construction sector increased from 27,579 to $111,760 \times 10^{4}$ tons of coal equivalent (tce). We further find that the construction sector has the largest inflows of energy consumption to obtain its own demand than other sectors from 2002 to 2018. The average annual energy consumption net flows from other seven sectors to the construction sector were $1477,687,47,998,6067,1483,7362$ and $1923 \times 10^{4}$ tce in 2002-2018, respectively. Moreover, we find that the Manufacturing sector is the largest energy supplier of the construction sector between 2002 and 2018.
\end{abstract}

Keywords: energy consumption; the construction sector; linkage; modified hypothetical extraction method

\section{Introduction}

With increasingly serious global warming, the issue of energy consumption cannot be ignored. Energy consumption of construction sector has become a crucial part in global energy consumption [1-6]. Construction sector as the one of the highest energy consumption sectors in China, is the core sector of Chinese energy consumption [7]. According to statistics by National Bureau of Statistics of China, the energy consumption of construction sector in China has increased from 5533 to $9142 \times 10^{4}$ tce $(1$ tce $=29.3 \mathrm{GJ})$ during the period between 2010 and 2019, with the average annual growth rate of $6.5 \%$. It is observed that the energy consumption of Chinese construction sector still experiences a growing trend. Besides, with the continuous increase of China's construction scale, the energy consumption of China's construction sector will continue rising [8-10].

In order to solve the problem of global warming, countries around the world are confronted with the common goal of $\mathrm{CO}_{2}$ emission reduction [11-17]. In recent decades, Chinese rapid economic development has been accompanied by a relatively large amount of energy consumption [18,19]. Chinese government not only introduces energy conservation and emission reduction as the basic state policy [20], but also establish the target to peak its $\mathrm{CO}_{2}$ emissions before 2030 in the Paris Agreement. It is admitted that the construction sector plays a crucial part in global energy conservation and emission reduction across sectors [21-23]. Similarly, the construction sector is equally key to realize the target of energy conservation and emission reduction in China $[7,24,25]$. Therefore, energy consumption of 
the Chinese construction sector has attracted significant attention in academia for many years [18,26-29].

The common practice is to use direct consumption to evaluate energy consumption, whereas it is not systematic to merely emphasize direct energy consumption [30]. In a national economy, the output of one sector is probably other sectors' input, which means the interdependence among different sectors rather than independence [31]. Theoretically, the production processes in which one sector is interdependent with other sectors is defined as linkages [32]. The linkages among different sectors can introduce three energy consumption situations as follows. Firstly, there are direct and indirect energy consumption in actual commodity production and service activities [29,30,33,34]. Secondly, as the basic inputoutput relationship illustrates, products of a sector requires products from other sectors as the intermediate input and goods produced by this sector can further become other sectors' intermediate input, because all of these products of the sectors need energy as input, energy consumption of sectors has linkage effect [35]. Thirdly, input and output of commodities or service among different sectors means energy flow among different sectors $[30,36]$. It is worthy stressing that the construction sector as the pillar of economy in China is critical to national economic development and it closely interacts with other sectors in the economic system $[24,31,37]$. Therefore, quantitative analysis of the indirect consumption, linkage of energy consumption and energy flow of China's construction sector would assist in achieving the goal of energy conservation and emission reduction.

From a methodological viewpoint, input-output analysis has become an approach that is widely applied in the field of energy [38-42]. In compliance with input-output analysis, Schultz [43] analyzed linkages among 20 standard sectors for the first time using hypothetical extraction method (HEM), this method suppose that a sector is eliminated and then compare total output changes in the economic system before and after the removal of this sector, aiming to measure the importance of this sector in the whole economic system and quantitatively analyze impacts on other sectors. HEM is generally applied to research the economic effect of a sector [42-48], and identification of a key sector to formulate targeted policies based on the analysis results [49-52], even extended to resource consumption and carbon emission research fields to analyze the linkages of resources consumption and carbon emission of different countries or regions [53-58]. On the foundation of HEM, Duarte et al. [59] pointed out that modified hypothetical extraction method (MHEM) calculates the vertically integrated consumption and divide linkage effect into four components which aims to analyze the linkage of water use in Spain. In addition to the studies of linkage of water use [60], MEHM is also involved in researches of $\mathrm{CO}_{2}$ emission [61-65]. Although an increasingly number of scholars have used MHEM, there are few studies that focus on the linkage of energy consumption between a single sector and the rest of the Chinese economic system.

Different from previous studies, this research is expected to apply MHEM to the linkage of energy consumption, concentrating on the linkage of energy consumption between Chinese construction sector and the rest of the economic sectors. Then, we calculate indirect energy consumption of Chinese construction sector using the national input-output table and energy consumption by sector from China (National Bureau of Statistics of China, 2002, 2005, 2007, 2010, 2012, 2015, 2017 and 2018). From the linkage of energy consumption perspective, we quantitatively analyzed the internal consumption, mixed consumption, net backward linkage consumption and net forward linkage consumption of Chinese construction sector, which aimed at investigating impacts of energy consumption of construction on the entire economic system and further revealing energy flow paths and volumes from other sectors to the construction sector. 


\section{Methodology}

\subsection{Energy Consumption Input-Output Model}

The fundamental input-output model is described below:

$$
X=(I-A)^{-1} Y
$$

where $X$ is an $n \times 1$ vector of total output with elements $x_{i}$, where $n$ stands for number of industries in the economy; $I$ is the identity matrix; $A$ is $n$-by- $n$ matrix of technical coefficients, whose element $a_{i j}$ measures the flow from industry $i$ required to produce the per unit output of industry $j$ (where $i, j=1, \ldots, n) ;(I-A)^{-1}$ is the Leontief inverse matrix, in which elements show the output of a sector required directly and indirectly to produce the per unit of final demand for the other sector. $Y$ is an $n \times 1$ vector of final demands with elements $y_{i}$.

The energy consumption input-output model which is derived from the structure of the fundamental input-output equation. First, the direct energy consumption coefficient is defined as:

$$
\rho=D C / X
$$

where $D C$ is direct energy consumption. Combining Equations (1) and (2), the energy input-output model is described below:

$$
\omega=\rho(I-A)^{-1} Y=B^{\rho} \times Y
$$

where $\omega$ is the energy input-output matrix; $B^{\rho}$ is the matrix of total energy consumption coefficient with elements $b_{i j}{ }^{\rho}$ demonstrating the total volumes of direct and indirect energy consumption generated per unit's worth of final demand presented to the economy.

\subsection{Linkage Analysis of Energy Consumption by HEM}

HEM was first used by Schultz [43] to research the economic impact of a sector's activity change. The original idea of the HEM is to extract a sector from the economic system under hypothetical situations and then to measure the effect of this extraction on other sectors in the economy. Linkage analysis of energy consumption by HEM in greater details as described below, it is assumed that the economy has been partitioned into two blocks: $Z_{t}$ is block one, while $Z_{-t}$ is block two. Both block $Z_{t}$ and $Z_{-t}$ can represent a single sector or several sectors, and the economy as follows:

$$
Z=\left[\begin{array}{cc}
Z_{t, t} & Z_{t,-t} \\
Z_{-t, t} & Z_{-t,-t}
\end{array}\right]
$$

Combining Equations (3) and (4), the energy consumption matrix before a sector is extracted can be expressed as:

$$
\left[\begin{array}{c}
\omega_{t} \\
\omega_{-t}
\end{array}\right]=\left[\begin{array}{cc}
\rho_{t} & 0 \\
0 & \rho_{-t}
\end{array}\right]\left[\begin{array}{cc}
\exists_{t, t} & \unlhd_{t,-t} \\
\unlhd_{-t, t} & \unlhd_{-t,-t}
\end{array}\right] \times\left[\begin{array}{c}
Y_{t} \\
Y_{-t}
\end{array}\right]
$$

where $(I-A)^{-1}=\left[\begin{array}{cc}\unlhd_{t, t} & \dashv_{t,-t} \\ \unlhd_{-t, t} & \unlhd_{-t,-t}\end{array}\right]$ is the Leontief inverse matrix.

Block $Z_{t}$ is to be hypothetically extracted from the economy, block $Z_{t}$ and $Z_{-t}$ neither have economic activity. The hypothetical energy consumption relationships are shown below:

$$
\left[\begin{array}{c}
\omega^{*}{ }_{t} \\
\omega^{*}{ }_{t}
\end{array}\right]=\left[\begin{array}{cc}
\rho_{t} & 0 \\
0 & \rho_{-t}
\end{array}\right]\left[\begin{array}{cc}
\left(I-A_{t, t}\right)^{-1} & 0 \\
0 & \left(I-A_{-t,-t}\right)^{-1}
\end{array}\right] \times\left[\begin{array}{c}
Y_{t} \\
Y_{-t}
\end{array}\right]
$$


The change in energy consumption, which reflects the impact of the extracted block can be obtained by subtracting Equation (5) from Equation (6):

$$
\begin{aligned}
& {\left[\begin{array}{c}
\omega_{t} \\
\omega_{-t}
\end{array}\right]-\left[\begin{array}{c}
\omega^{*}{ }_{t} \\
\omega^{*}{ }_{t}
\end{array}\right]=} \\
& {\left[\begin{array}{c}
\omega_{t}-\omega^{*}{ }_{t} \\
\omega_{-t}-\omega^{*}{ }_{-t}
\end{array}\right]=\left[\begin{array}{cc}
\rho_{t} & 0 \\
0 & \rho_{-t}
\end{array}\right]\left[\begin{array}{cc}
\exists_{t, t}-\left(I-A_{t, t}\right)^{-1} & \exists_{t,-t} \\
\lrcorner_{-t, t} & \unlhd_{-t,-t}-\left(I-A_{-t,-t}\right)^{-1}
\end{array}\right] \times\left[\begin{array}{c}
Y_{t} \\
Y_{-t}
\end{array}\right]} \\
& =\left[\begin{array}{cc}
\rho_{t}\left(\exists_{t, t}-\left(I-A_{t, t}\right)^{-1}\right) & \rho_{t} \exists_{t,-t} \\
\left.\rho_{-t}\right\lrcorner_{-t, t} & \rho_{-t}\left(\exists_{-t,-t}-\left(I-A_{-t,-t}\right)^{-1}\right)
\end{array}\right] \times\left[\begin{array}{c}
Y_{t} \\
Y_{-t}
\end{array}\right] \\
& =\left[\begin{array}{cc}
\xi_{t, t} & \xi_{t,-t} \\
\xi_{-t, t} & \xi_{-t,-t}
\end{array}\right] \times\left[\begin{array}{c}
Y_{t} \\
Y_{-t}
\end{array}\right]
\end{aligned}
$$

According to Equation (7), the total, backward and forward energy consumption linkage by HEM are defined as follows:

$$
\begin{gathered}
T E L=v^{\prime}\left[\begin{array}{c}
\omega_{t}-\omega^{*}{ }_{t} \\
\omega_{-t}-\omega^{*}{ }_{-t}
\end{array}\right] \\
B E L=v^{\prime}\left[\begin{array}{cc}
\xi_{t, t} & \xi_{-t, t}
\end{array}\right] Y_{t} \\
F E L=v^{\prime}\left[\begin{array}{c}
\xi_{t,-t} \\
\xi_{-t,-t}
\end{array}\right] Y_{-t}
\end{gathered}
$$

where $v^{\prime}$ is the identity vector. At the same time, Equations (8)-(10) possess the following relation: $T E L=B E L+F E L$.

\subsection{Linkage Analysis of Energy Consumption by MHEM}

The modified hypothetical extraction method (MHEM) proposed by Duarte et al. [59] is based on the vertically integrated sector Pasinetti (1977) and HEM. From Equations (8)-(10) they decompose the water use associated with $Z_{c}$ into four separate components, namely: internal effect, mixed effect, net backward linkage and net forward linkage. According to MHEM, this study is conducted to construct the vertically integrated consumption of energy (VICE), and then decompose energy consumption into the internal consumption $(I C)$, mixed consumption $(M C)$, net backward linkage consumption (NBLC) and net forward linkage consumption (NFLC).

VICE can be obtained as follows:

$$
\operatorname{VICE} E_{j}=\sum_{i=1}^{n} \rho_{i} \eta_{i j} Y_{j}
$$

where $V I C E_{j}$ is the total volumes of direct and indirect energy consumption to obtain the final demand sector $j ; \rho_{i}$ is the direct energy consumption coefficient of sector $i$; $\eta_{i j}$ is the element of the Leontief Inverse matrix; $Y_{j}$ is the final demand of sector $j$.

$I C$ is the energy consumed with the processes within the $Z_{t}$ itself $[66,67]$, which is stated as:

$$
I C=\rho_{t}\left(I-A_{t, t}\right)^{-1} Y_{t}
$$

$M C$ is the part of energy consumed that is associated with the participation of both $Z_{t}$ and $Z_{-t}$, representing the energy consume that are embodied in the goods which are originally sold to $Z_{-t}$ by $Z_{t}$, and after being processed by $Z_{-t}$, consequently repurchased by $Z_{t}$, for production purposes, and the formula of $\mathrm{MC}$ is as follows:

$$
M C=\rho_{t}\left[\exists_{t, t}-\left(I-A_{t, t}\right)^{-1}\right] Y_{t}
$$


$N B L C$ is the energy consume requirements of from $Z_{-t}$ to obtain the final demand of $Z_{t}$, which reflects the net energy consume inflows of $Z_{t}$. NBLC can be described as follows:

$$
\left.N B L C=\rho_{-t}\right\lrcorner_{-t, t} Y_{t}
$$

NFLC is the energy consume of $Z_{c}$ and used by $Z_{-t}$ for production, which represents the net energy consume exports of $Z_{t}$, and the formula of NBLC can be obtained as:

$$
\left.N F L C=\rho_{t}\right\lrcorner_{t,-t} Y_{-t}
$$

where $V I E, I C, M C$ and NBLC possess the following relations: $V I E=I C+M C+N B L C$.

Thus, the total of energy net flow (TENF) can be expressed by subtracting Equation (15) from Equation (14):

$$
T E N F=N F L C-N B L C
$$

In order to clarify the role of block in energy consumption, the concepts of energy supplier and energy receiver are proposed in this study. If TENF $>0$, which reflects energy flow from $Z_{t}$ to $Z_{-t}$, that is to say, $Z_{t}$ is the energy supplier; If $T E N F<0$, which reflects energy flow from $Z_{-t}$ to $Z_{t}$, that is to say, $Z_{t}$ is the energy receiver.

This study aims to explore the volumes and paths of energy flow among the different sectors. Assume block $-t_{1}$ is one of the blocks that make up $Z_{-t}$. Decomposing Equation (14), the volumes of energy flow from block $-t_{1}$ to block $Z_{t}$ can be defined as follows:

$$
N B L C_{-t_{1} \rightarrow t}=\rho_{-t_{1}} \sqsupset_{-t_{1}, t} Y_{t}
$$

Decomposing Equation (15), the volumes of energy flow from block $Z_{t}$ to block $-t_{1}$ can be defined as follows:

$$
\left.N F L C_{t \rightarrow-t_{1}}=\rho_{t}\right\lrcorner_{t,-t_{1}} Y_{-t_{1}}
$$

Then, the volumes and paths of energy net flow among blocks can be expressed by subtracting Equation (15) from Equation (14):

$$
E N F_{t \rightarrow-t_{1}}=N F L C_{t \rightarrow-t_{1}}-N B L C_{-t_{1} \rightarrow t}
$$

where a positive value of $E N F_{t \rightarrow-t_{1}}$ reflects energy flow from $Z_{t}$ to $-t_{1}$, which represents net output of energy; while a negative value of $E N F_{t \rightarrow-t_{1}}$ indicates energy flow from $-t_{1}$ to $Z_{t}$, which represents net input of energy.

\section{Empirical Analysis}

\subsection{Data Source and Processing}

In this study, we measure the energy consumption linkages and energy flow of the construction sector in 2002, 2005, 2007, 2010, 2012, 2015, 2017 and 2018. Therefore, this paper requires two sets of data: the time series of input-output tables and the corresponding energy consumption. The input-output tables and energy consumption data come from China (National Bureau of Statistics of China, 2002, 2005, 2007, 2010, 2012, 2015, 2017 and 2018). It is necessary to indicate that China's National Bureau of Statistics compiles an input-output table based on national surveys every 5 years, during which an input-output is extended. Therefore, the most recent national input-output table is 2018.

According to the classification in the input-output Table and the energy statistics of China, we allocated more than 100 sectors in the economy. In accordance with Industrial classification for national economic activities of China, these sectors were grouped into eight blocks. The eight blocks are as follows: Agriculture (U1), Mining (U2), Manufacturing (U3), Production and Supply of Electricity Power, Heat Power, Gas and Water (U4), Construction (U5), Retail and catering industry (U6), Transportation (U7) and Other Industries (U8). 


\subsection{Direct and Indirect Energy Consumption}

Figure 1 shows both the direct and indirect energy consumptions of the construction sector. The direct energy consumption is derived from National Bureau of Statistics of China. And the indirect energy consumption is obtained by subtracting the direct energy consumption from Equation (11). As shown in Figure 1, the direct and indirect energy consumptions of the construction sector kept increasing over the 2002-2012 period. It is worth noting that, although the direct energy consumption in the construction sector of China was relatively small, it had large indirect energy consumption. More specifically, the indirect energy consumption all exceeded the direct energy consumption between 2002 and 2018, representing more than $90 \%$ of total (direct plus indirect) energy consumption. Between 2002 and 2018, the indirect energy consumption of the construction sector increased from 27,579 to $111,760 \times 10^{4}$ tce. In the construction sector, the indirect energy consumption has a significant effect on VICE (the total energy consumption to satisfy the final demand). This implies that the sectoral linkages between the construction sector and other economic sectors cannot be ignored when exploring energy consumption of the whole economy.

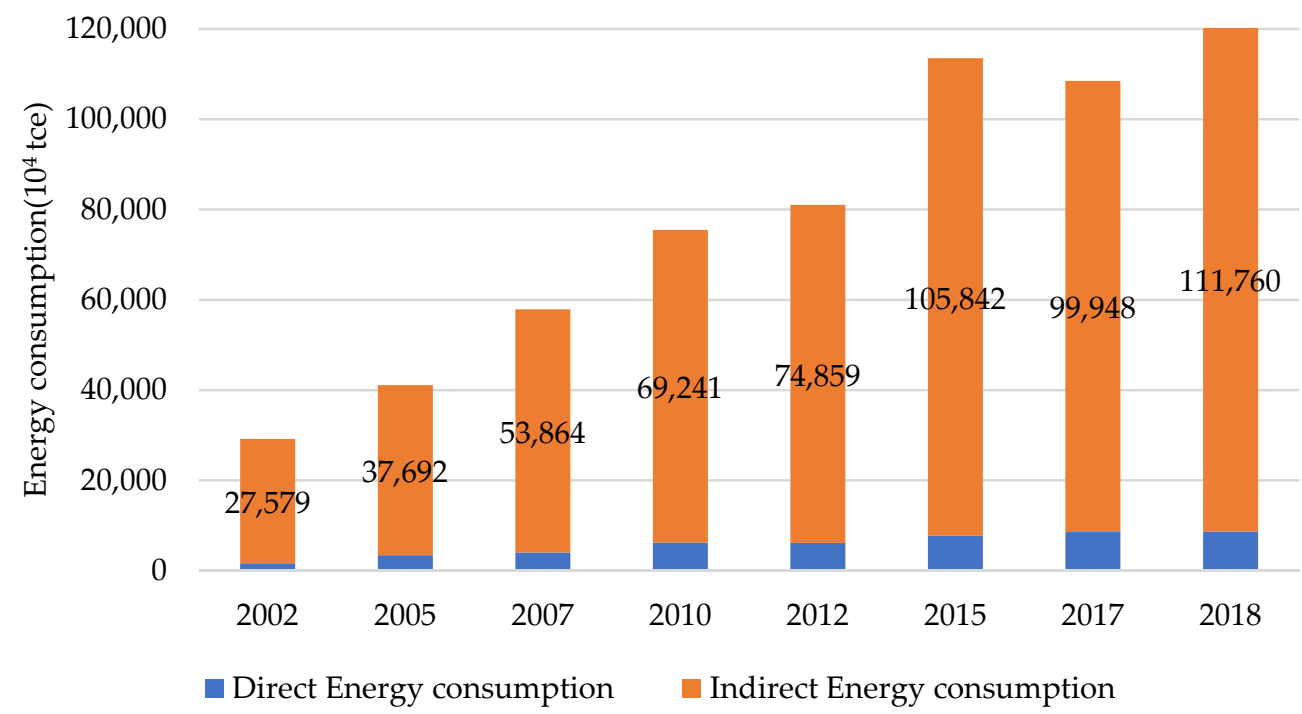

Figure 1. The direct and indirect energy consumptions of the Chinese construction sector in 2002-2018.

\subsection{Linkage of Energy Consumption}

For other seven blocks, the energy consumption linkages of the construction sector in different periods are shown in Table 1. Four significant differences can be observed among the ranks of the internal consumption, mixed consumption, net backward linkage consumption and net forward linkage consumption. First, except for 2010 and 2015, all ranking values of the internal consumption of the construction sector are below number 3 . Second, all values of the mixed consumption of the construction sector are ranked in the number 7. Third, the net backward linkage consumption of the construction sector all exceeded the other three linkages in 2002-2018, which means that there are greater consumption inflows. Between 2002 to 2018, the net backward linkage of the construction sector increased from 27,670 to $111,877 \times 10^{4}$ tce. The construction sector has the largest net backward linkage of energy consumption than other seven blocks from 2002 to 2018, which indicates the construction sector has the largest inflows of energy to obtain its own demand. Last, the net forward linkage consumption of the construction sector was the least. Low net forward linkage consumption means that the construction sector emits little energy in providing outputs required by other blocks. 
Table 1. The four components of energy consumption linkages in construction sector, 2002-2018 $\left(10^{4}\right.$ tce).

\begin{tabular}{|c|c|c|c|c|c|c|c|c|c|c|c|c|c|c|c|c|}
\hline \multirow{2}{*}{ Linkage } & \multicolumn{2}{|c|}{2002} & \multicolumn{2}{|c|}{2005} & \multicolumn{2}{|c|}{2007} & \multicolumn{2}{|c|}{2010} & \multicolumn{2}{|c|}{2012} & \multicolumn{2}{|c|}{2015} & \multicolumn{2}{|c|}{2017} & \multicolumn{2}{|c|}{2018} \\
\hline & Value & Rank & Value & Rank & Value & Rank & Value & Rank & Value & Rank & Value & Rank & Value & Rank & Value & Rank \\
\hline IC & 1506 & 7 & 3129 & 4 & 3940 & 4 & 6080 & 3 & 5942 & 4 & 7455 & 3 & 8431 & 4 & 8544 & 4 \\
\hline $\mathrm{MC}$ & 13 & 7 & 32 & 7 & 12 & 7 & 21 & 7 & 38 & 7 & 54 & 7 & 21 & 7 & 24 & 7 \\
\hline NBLC & 27,670 & 1 & 37,940 & 1 & 53,943 & 1 & 69,366 & 1 & 75,046 & 1 & 106,030 & 1 & 100,050 & 1 & 111,877 & 1 \\
\hline NFLC & 91 & 8 & 248 & 8 & 79 & 8 & 125 & 8 & 187 & 8 & 188 & 8 & 102 & 8 & 117 & 8 \\
\hline
\end{tabular}

\subsection{Components of VICE}

According to Equations (11)-(14), Figure 2 shows the VICE (the total energy consumption to satisfy the final demand) composition of the construction sector. It can be noted that more than $91 \%$ of the VICE in the construction sector comes from NBLC. This high NBLC ratio indicates that a significant part of the directly and indirectly energy consumed by the construction sector comes from inflows from the other blocks in 2002-2018. Between 2002 to 2018, the value of internal consumption was stabilizing at a low value less than $8.1 \%$. The low internal consumption, demonstrating significant non-dominance of internal consumption in the construction sector. Additionally, the value of mixed consumption of the construction sector was less than $0.09 \%$ in 2002-2018. Similarly, the low mixed consumption reflects that the energy consumption component associated with the participation of the construction sector and other blocks is the least.

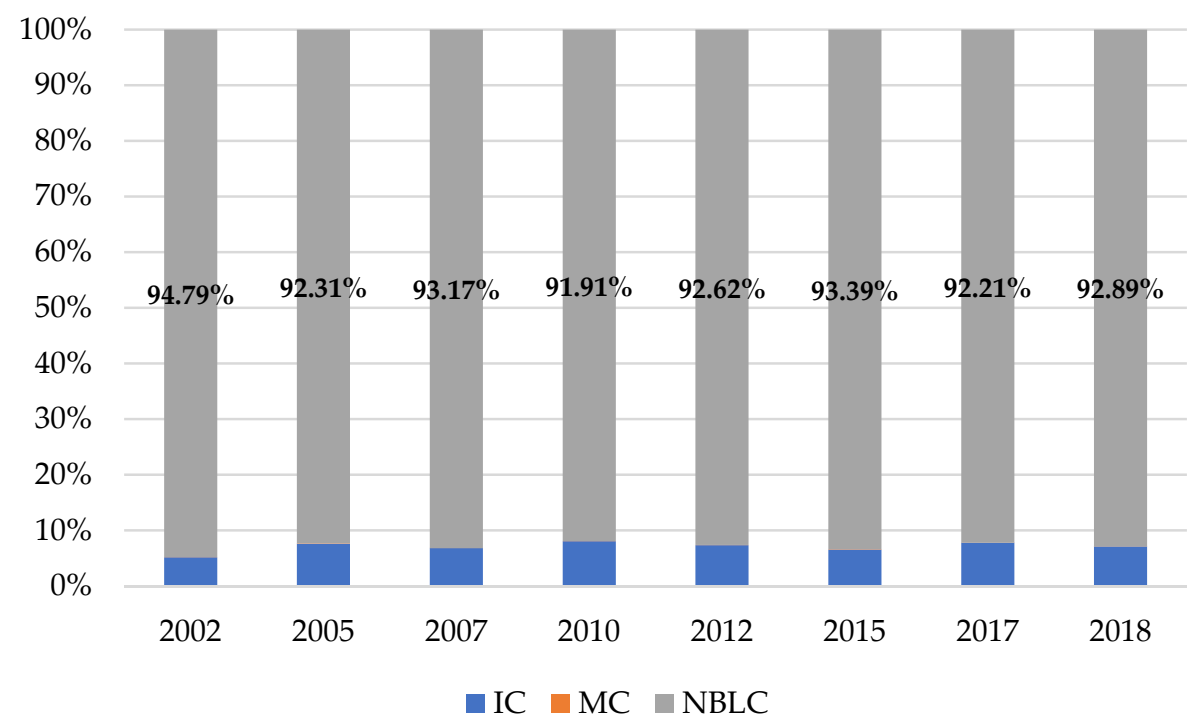

Figure 2. VICE composition of the construction sector in eight different years. Note: the VICE stands for total energy consumption to satisfy the final demand.

\subsection{Total of Energy Net Flow (TENF)}

The total of energy net flow in Figure 3 is obtained using Equation (16). As shown in Figure 3, TENF of the construction sector are all negative in 2002-2018, which means that energy flow from other blocks to the construction sector, that is to say, the construction sector is the energy receiver between 2002 and 2018. In this part, we also can get the tendency of TENF from 2002 to 2018. In 2002-2018, the energy flow from other blocks to the construction sector is mounting. For the construction sector, the imported energy consumption increased from 27,575 to $111,760 \times 10^{4}$ tce between 2002 and 2018. Thus, the volumes and paths of energy net flow from other blocks to the construction sector has an increasingly important impact on the whole economy's energy consumption. 


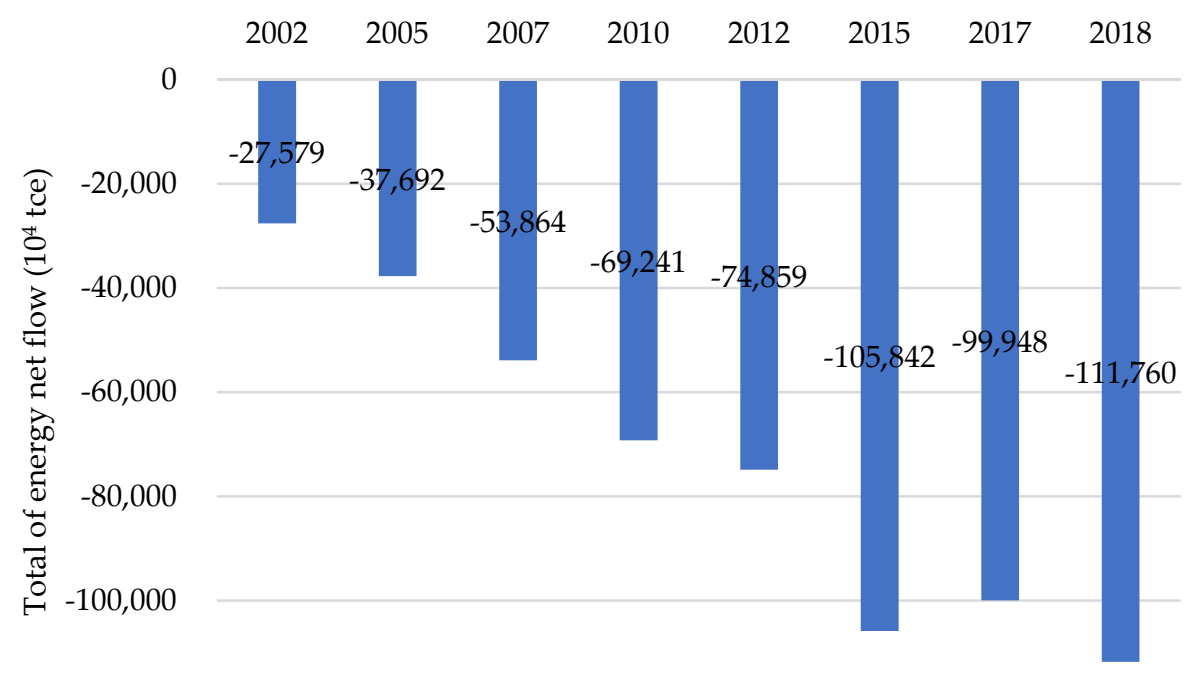

$-120,000$

Figure 3. The total of energy net flow of the Chinese construction sector, 2002-2018.

\subsection{Net Flow of Energy Consumption}

According to Equation (19), the clear understanding of the construction sector's energy consumption linkages between 2002 and 2018 were obtained as shown in Figure 4. The flow paths and volumes of energy consumption in different sectors can be found in Figure 4, and then we can see where the energy consumption of the construction sector comes from. Where Figure 4a shows the net flow of energy consumption in 2018. The development of the other seven blocks also had a pull effect on the energy consumption in the construction sector. In 2018, the imported net flow of energy consumption to the construction sector is from the other seven blocks. Specifically, the construction sector with 1858, 9061, 74,535, 9232, 2857, 10,516 and $3701 \times 10^{4}$ tce energy consumption net flow from the Agriculture, Mining, Manufacturing, Production and Supply of Electricity Power, Heat Power, Gas and Water, Retail and catering industry, Transportation and Other Industries, respectively, where Manufacturing occupies the largest proportion.

From Figure $4 \mathrm{~b}$ it is clearly seen that the average of the net flow of energy consumption between 2002 and 2018. It can be noted that the average annual energy consumption net flow from the Agriculture, Mining, Manufacturing, Production and Supply of Electricity Power, Heat Power, Gas and Water, Retail and catering industry, Transportation and Other Industries flow to the construction sector were 1477, 6287, 47,998, 6067, 1483, 7362 and $1923 \times 10^{4}$ tce in 2002-2018, respectively, where Manufacturing occupies the largest proportion.

The percentages of energy consumption net flow from other seven blocks to the construction sector in Table 2 is obtained using Figure 4. Where row(a) shows the percentages of energy consumption net flow from other sectors to the construction sector in 2018. It can be noted that the percentage of Manufacturing was $66.69 \%$. The percentages of other six sectors were $1.66 \%, 8.11 \%, 8.26 \%, 2.56 \%, 9.41 \%$ and $3.31 \%$, respectively. Thus, Manufacturing is the largest energy supplier of the construction sector in 2018. This suggests that Manufacturing has the largest relative impact on energy consumption net flow of the construction sector in 2018.

Table 2. The percentages of energy consumption net flows of construction sector.

\begin{tabular}{ccccccccc}
\hline Sector & U1 & U2 & U3 & U4 & U6 & U7 & U8 & Total \\
\hline a & $1.66 \%$ & $8.11 \%$ & $66.69 \%$ & $8.26 \%$ & $2.56 \%$ & $9.41 \%$ & $3.31 \%$ & $100.00 \%$ \\
b & $2.03 \%$ & $8.66 \%$ & $66.12 \%$ & $8.36 \%$ & $2.04 \%$ & $10.14 \%$ & $2.65 \%$ & $100.00 \%$ \\
\hline
\end{tabular}

Note: The total of energy net flows to the construction sector is $100 \%$. Row(a) shows the percentages of energy consumption net flows in 2018. Row(b) shows the averages of percentages of energy consumption net flows between 2002 and 2018. 


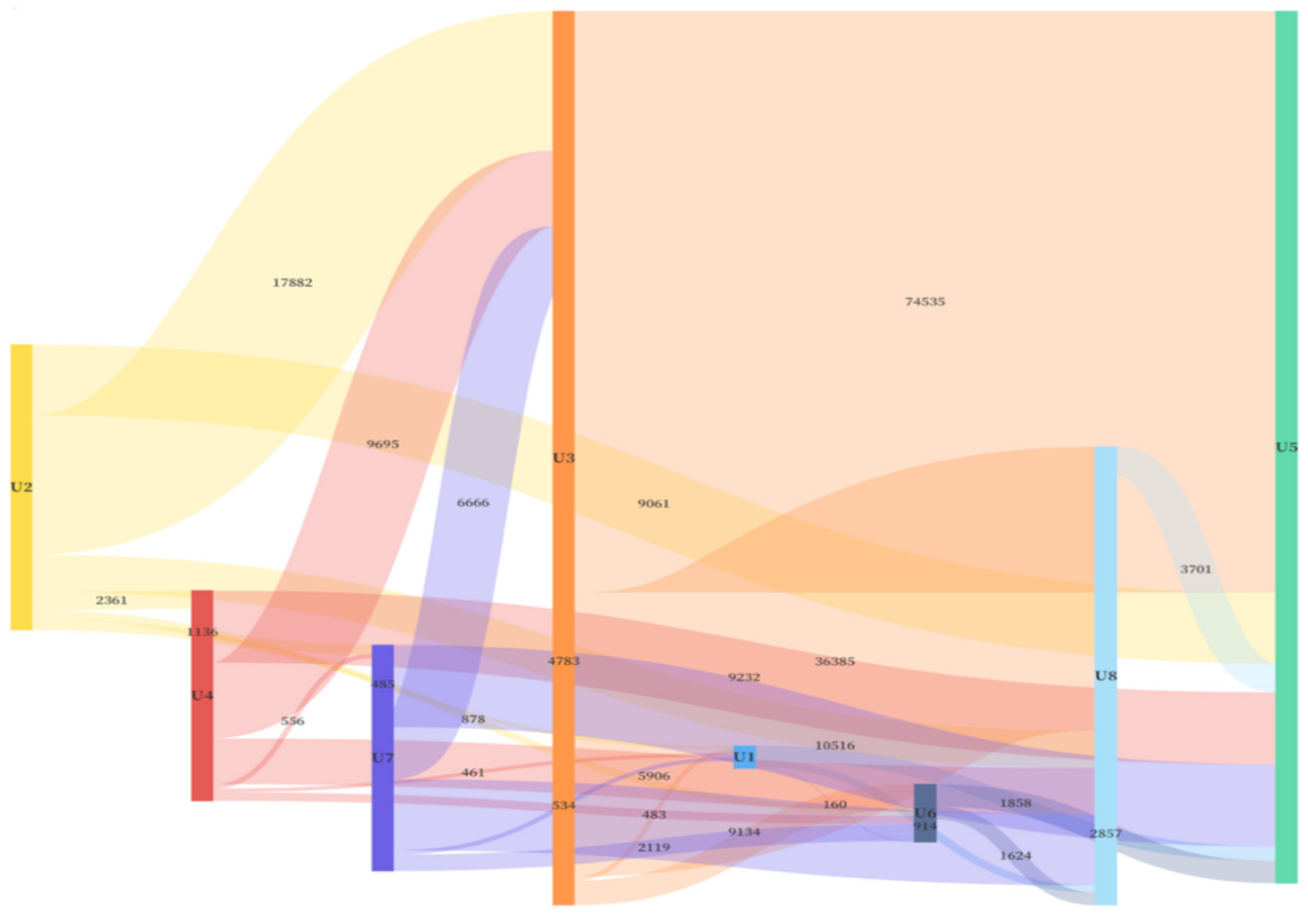

(a)

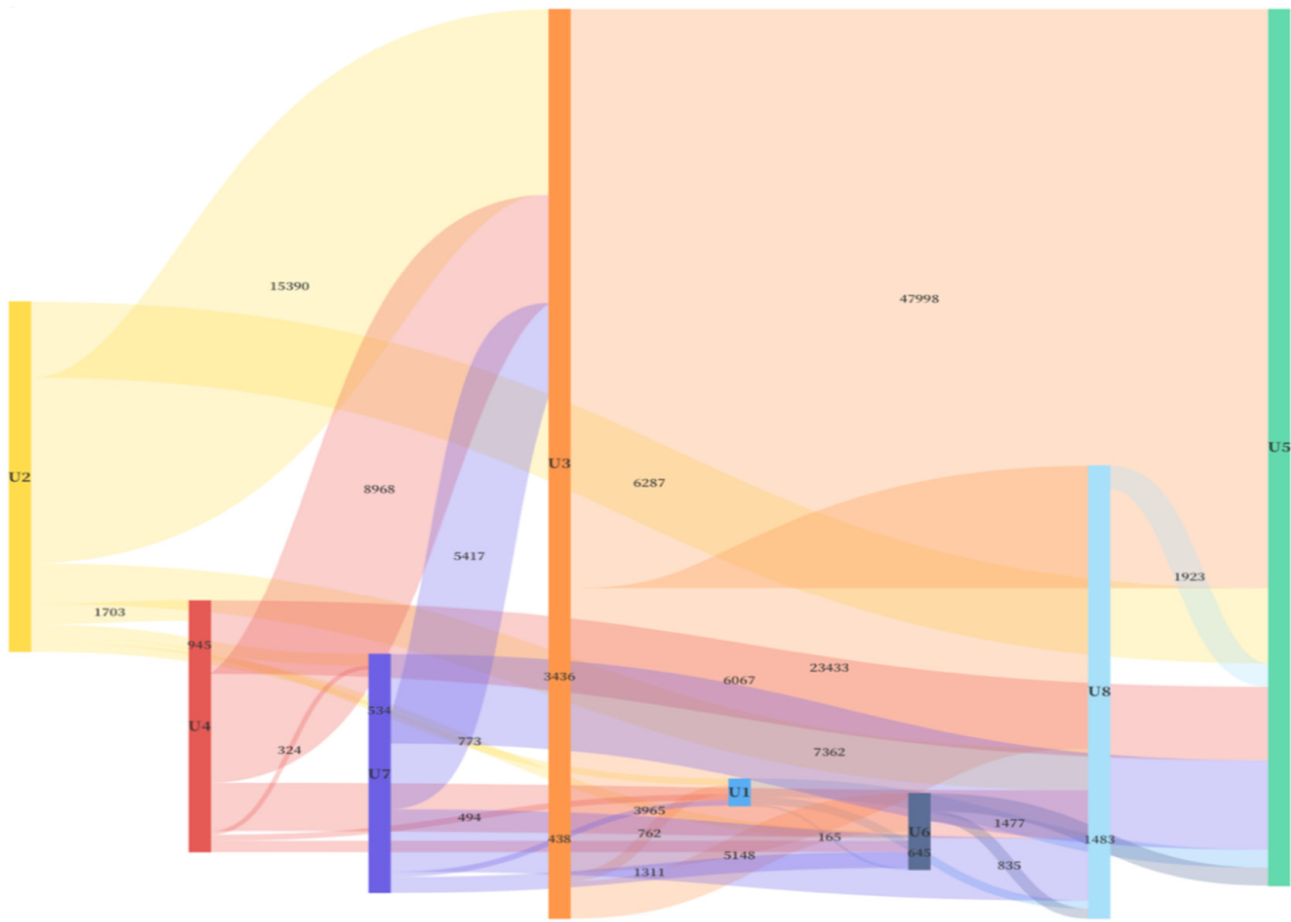

(b)

Figure 4. The net flow paths and volumes of energy consumption in different sectors of China $\left(10^{4}\right.$ tce). Note: (a) Shows the net flow of energy consumption in 2018. (b) Shows the average of the net flow of energy consumption between 2002 and 2018. Colors indicate the eight different sectors. Energy consumption flows from the sectors on the left to the sectors on the right. The width of the line represents the volumes of energy consumption net flow, and the specific volumes are shown in the middle. 
The averages of percentages of energy consumption net flow from other sectors to the construction sector between 2002 and 2018 were obtained as shown in row $(b)$. The average percentage of Manufacturing was $66.12 \%$. The percentages of other six sectors were $2.03 \%, 8.66 \%, 8.36 \%, 2.04 \%, 10.14 \%$ and $2.65 \%$, respectively. Similarly, in the case of energy for construction sector we can find that the Manufacturing is the largest energy supplier between 2002 and 2018.

\section{Conclusions and Policy Implications}

The construction sector is important to realize the target of energy conservation and emission reduction in China. Besides, energy consumption in China's construction sector has attracted significant attention in academia for many years. Different from previous studies, this research aimed to apply MHEM to the linkage of energy consumption, concentrating on the linkage of energy consumption between Chinese construction sector and the rest of the economic sectors. Understanding the energy consumption relationship between the construction sector and other sectors can provide useful information for the target of energy conservation and emission reduction in China. Therefore, we used MHEM to calculate indirect energy consumption of Chinese construction sector in 2002, 2005, 2007, 2010, 2012, 2015, 2017 and 2018. Then, we quantitatively analyzed the energy consumption linkages between construction sector and the rest of economy, and further revealing energy flow paths and volumes from other sectors to the construction sector. Moreover, we analyzed the relative impact of other sectors on the construction sector by relative percentages of energy consumption net flow. It is necessary to indicate that China's National Bureau of Statistics compiles an input-output table based on national surveys every 5 years, during which an input-output is extended. The most recent national input-output table is 2018. Therefore, the dataset in this paper is complete. Based on our analysis, the following key conclusions are drawn:

First, the direct and indirect energy consumptions of the construction sector kept increasing over the 2002-2012 period. Although the direct energy consumption in the construction sector of China was relatively small, it had large indirect energy consumption. More specifically, the indirect energy consumption all exceeded the direct energy consumption between 2002 and 2018, representing more than 90\% of total (direct plus indirect) energy consumption. Between 2002 and 2018, the indirect energy consumption of the construction sector increased from 27,579 to $111,760 \times 10^{4}$ tce. This indicates that the sectoral linkages between the construction sector and other economic sectors cannot be ignored when exploring energy consumption of the whole economy.

Second, the construction sector has the largest inflows of energy to obtain its own demand than other sectors from 2002 to 2018. For the construction sector, the total of imported energy consumption increased from 27,575 to $111,760 \times 10^{4}$ tce between 2002 and 2018. Between 2002 to 2018, the net backward linkage of the construction sector increased from 27,670 to 111,877 . The construction sector has the largest net backward linkage of energy consumption compared with other seven blocks from 2002 to 2018. And the net forward linkage consumption of the construction sector was the least. This means that the construction sector has the largest inflows of energy to obtain its own demand.

Finally, the net energy consumption flow from the Agriculture, Mining, Manufacturing, Production and Supply of Electricity Power, Heat Power, Gas and Water, Retail and catering industry, Transportation and Other Industries to the construction sector was identified, in which Manufacturing occupies the largest proportion in 2018 (according to Table 2, the relative percentage is $466.84 \%$ ). Moreover, we can find that Manufacturing is the largest energy supplier of the construction sector between 2002 and 2018 (according to Table 2, the relative percentage is $462.81 \%$ ).

Through the analysis of the research results, some specific energy policy implications can be made to contribute to play the role of China's construction sector in promoting energy conservation and emission reduction. First, although the direct energy consumption of the Chinese construction sector is less, the indirect energy consumption is large. Therefore, it is 
imperative to improve the energy efficiency in the construction sector and reduce energy loss, which plays an important role in energy conservation and emission reduction. Second, the net inflows of energy to construction sector is from the other seven sectors. Additionally, the manufacturing sector is the largest energy supplier of the construction sector. Therefore, in order to reduce the energy consumption of the construction sector, the energy inflows from other sectors should be reduced. Among them, the manufacturing should be regarded as the key sector. Finally, the government should reasonably increase the investment in green technology innovation to encourage construction companies to reduce energy use and pollutant emissions.

This research provides a good opportunity to study the energy consumption relationship between the construction sector and other sectors in China. Nevertheless, the study is limited to the sectors in the economic system. Some discussions in terms of the Life Cycle Assessment for the kind of analysis conducted in this research will surely produce reliable outcomes for energy consumption linkages in the future research.

Author Contributions: Conceptualization, Z.L. and Y.S.; methodology, Z.L. and Y.S.; software, Z.L. and Y.S.; validation, Z.L. and Y.S.; formal analysis, Z.L. and Y.S.; investigation, Z.L. and Y.S.; resources, Z.L. and Y.S.; data curation, Z.L. and Y.S.; writing-original draft preparation, Z.L. and Y.S.; writing-review and editing, Z.L. and Y.S.; visualization, Z.L. and Y.S.; supervision, Z.L. and Y.S.; project administration, Z.L. and Y.S. All authors have read and agreed to the published version of the manuscript.

Funding: This research was funded by the Faculty Research Grants (FRG) of Macau university of science and technology, project title: Linkage losses measurement based on the weighted hypothetical extraction method.

Institutional Review Board Statement: Not applicable.

Informed Consent Statement: Not applicable.

Data Availability Statement: Not applicable.

Acknowledgments: Authors' gratitude is extended to the prospective editor(s) and reviewers that will/have spared time to guide toward a successful publication.

Conflicts of Interest: The authors declare no conflict of interest.

\section{References}

1. Zhong, H.; Wang, J.J.; Jia, H.J.; Mu, Y.F.; Lv, S.L. Vector field-based support vector regression for building energy consumption prediction. Appl. Energy 2019, 242, 403-414. [CrossRef]

2. Amasyali, K.; El-Gohary, N.M. A review of data-driven building energy consumption prediction studies. Renew. Sustain. Energy Rev. 2018, 81, 1192-1205. [CrossRef]

3. Sattary, S.; Thorpe, D. Potential carbon emission reductions in Australian construction systems through bioclimatic principles. Sustain. Cities Soc. 2016, 23, 105-113. [CrossRef]

4. Liu, B.; Zhang, L.; Sun, J.D.; Wang, D.D.; Liu, C.L.; Luther, M.; Xu, Y.Q. Composition of energy outflows embodied in the gross exports of the construction sector. J. Clean. Prod. 2020, 248, 119296. [CrossRef]

5. Tabrizikahou, A.; Nowotarski, P. Mitigating the energy consumption and the carbon emission in the building structures by optimization of the construction processes. Energies 2021, 14, 3287. [CrossRef]

6. Mercader-Moyano, P.; Anaya-Durán, P.; Romero-Cortés, A. Eco-efficient ventilated facades based on circular economy for residential buildings as an improvement of energy conditions. Energies 2021, 14, 7266. [CrossRef]

7. Cai, W.G.; Wu, Y.; Zhong, Y.; Ren, H. China building energy consumption: Situation, challenges and corresponding measures. Energy Policy 2009, 37, 2054-2059. [CrossRef]

8. Yang, Y.C.; Liu, J.H.; Lin, Y.Y.; Li, Q.Y. The impact of urbanization on China's residential energy consumption. Struct. Chang. Econ. Dyn. 2019, 49, 170-182. [CrossRef]

9. Zhang, Y.; Yan, D.; Hu, S.; Guo, S.Y. Modelling of energy consumption and carbon emission from the building construction sector in China, a process-based LCA approach. Energy Policy 2019, 134, 110949. [CrossRef]

10. Guo, S.; Zheng, S.P.; Hu, Y.H.; Hong, J.K.; Wu, X.F.; Tang, M.H. Embodied energy use in the global construction industry. Appl. Energy 2019, 256, 113838. [CrossRef]

11. Jeong, K.; Hong, T.; Kim, J. Development of a $\mathrm{CO}_{2}$ emission benchmark for achieving the national $\mathrm{CO}_{2}$ emission reduction target by 2030. Energy Build. 2018, 158, 86-94. [CrossRef] 
12. Ionescu, L. Transitioning to a low-carbon economy: Green financial behavior, climate change mitigation, and environmental energy sustainability. Geopolit. Hist. Int. Relat. 2021, 13, 86-96.

13. Ionescu, L. Leveraging green finance for low-carbon energy, sustainable economic development, and climate change mitigation during the COVID-19 Pandemic. Rev. Contemp. Philos. 2021, 20, 175-186.

14. Pflugmann, F.; De Blasio, N. The geopolitics of renewable hydrogen in low-carbon energy markets. Geopolit. Hist. Int. Relat. 2020, $12,9-44$.

15. Harrower, K. Networked and integrated urban technologies in sustainable smart energy systems. Geopolit. Hist. Int. Relat. 2020, $12,45-51$.

16. Eysenck, G. Sensor-based big data applications and computationally networked urbanism in smart energy management systems. Geopolit. Hist. Int. Relat. 2020, 12, 52-58.

17. Kovacova, M.; Lăzăroiu, G. Sustainable organizational performance, cyber-physical production networks, and deep learningassisted smart process planning in industry 4.0-based manufacturing systems. Econ. Manag. Financ. Markets 2021, 16, 41-54.

18. Xu, G.Y.; Wang, W.M. China's energy consumption in construction and building sectors: An outlook to 2100. Energy 2020, 195, 117045. [CrossRef]

19. Mi, Z.F.; Zheng, J.L.; Meng, J.; Shan, Y.L.; Zheng, H.R.; Ou, J.M.; Guan, D.B.; Wei, Y.M. China's energy consumption in the new normal. Earths Future 2018, 6, 1007-1016. [CrossRef]

20. Zhang, X.H.; Wu, L.Q.; Zhang, R.; Deng, S.H.; Zhang, Y.Z.; Wu, J.; Li, Y.W.; Lin, L.L.; Li, L.; Wang, Y.J.; et al. Evaluating the relationships among economic growth, energy consumption, air emissions and air environmental protection investment in China. Renew. Sustain. Energy Rev. 2013, 18, 259-270. [CrossRef]

21. Du, Q.; Huang, Y.D.; Xu, Y.D.; Bai, L.B.; Bao, T.N.; Wang, H.L. Benefit allocation in the construction supply chain considering carbon emissions. Pol. J. Environ. Stud. 2019, 28, 3697-3709. [CrossRef]

22. Liu, B.S.; Yang, X.D.; Huo, T.F.; Shen, G.Q.; Wang, X.Q. A linguistic group decision-making framework for bid evaluation in mega public projects considering carbon dioxide emissions reduction. J. Clean. Prod. 2017, 148, 811-825. [CrossRef]

23. Vasilca, I.-S.; Nen, M.; Chivu, O.; Radu, V.; Simion, C.-P.; Marinescu, N. the management of environmental resources in the construction sector: An empirical model. Energies 2021, 14, 2489. [CrossRef]

24. Zhou, D.Q.; Zhang, L.; Zha, D.L.; Wu, F.; Wang, Q.W. Decoupling and decomposing analysis of construction industry's energy consumption in China. Nat. Hazard. 2019, 95, 39-53. [CrossRef]

25. Lai, X.D.; Lu, C.; Liu, J.X. A synthesized factor analysis on energy consumption, economy growth, and carbon emission of construction industry in China. Environ. Sci. Pollut. Res. 2019, 26, 13896-13905. [CrossRef]

26. Huo, T.F.; Ren, H.; Zhang, X.L.; Cai, W.G.; Feng, W.; Zhou, N.; Wang, X. China's energy consumption in the building sector: A statistical yearbook-energy balance sheet based splitting method. J. Clean. Prod. 2018, 185, 665-679. [CrossRef]

27. Zhang, Y.; He, C.Q.; Tang, B.J.; Wei, Y.M. China's energy consumption in the building sector: A life cycle approach. Energy Build. 2015, 94, 240-251. [CrossRef]

28. Xue, X.L.; Wu, H.Q.; Zhang, X.L.; Dai, J.S.; Su, C. Measuring energy consumption efficiency of the construction industry: The case of China. J. Clean. Prod. 2015, 107, 509-515. [CrossRef]

29. Hong, J.K.; Shen, G.Q.; Guo, S.; Xue, F.; Zheng, W. Energy use embodied in China's construction industry: A multi-regional input-output analysis. Renew. Sustain. Energy Rev. 2016, 53, 1303-1312. [CrossRef]

30. Sun, X.Q.; An, H.Z.; Gao, X.Y.; Jia, X.L.; Liu, X.J. Indirect energy flow between industrial sectors in China: A complex network approach. Energy 2016, 94, 195-205. [CrossRef]

31. Zhang, L.; Liu, B.; Du, J.; Liu, C.L.; Wang, S. $\mathrm{CO}_{2}$ emission linkage analysis in global construction sectors: Alarming trends from 1995 to 2009 and possible repercussions. J. Clean. Prod. 2019, 221, 863-877. [CrossRef]

32. Khanal, B.R.; Gan, C.; Becken, S. Tourism inter-industry linkages in the Lao PDR economy: An input-output analysis. Tour. Econ. 2014, 20, 171-194. [CrossRef]

33. Liu, Z.; Geng, Y.; Lindner, S.; Zhao, H.Y.; Fujita, T.; Guan, D.B. Embodied energy use in China's industrial sectors. Energy Policy 2012, 49, 751-758. [CrossRef]

34. Lin, L.H.; Fan, Y.Z.; Xu, M.L.; Sun, C.W. A decomposition analysis of embodied energy consumption in China's construction industry. Sustainability 2017, 9, 1583. [CrossRef]

35. Deng, G.Y.; Zhang, Z.J. Research on the correlation effect of energy consumption in Chinese industries (industry) based on input-output decomposition model. Inquiry Econ. Issues 2017, 11, 95-102.

36. Zhang, J.H.; Wang, H.M.; Ma, L.; Wang, J.; Wang, J.S.; Wang, Z.; Yue, Q. Structural path decomposition analysis of resource utilization in China, 1997-2017. J. Clean. Prod. 2021, 322, 129006. [CrossRef]

37. Zhang, J.H.; Liu, Y.S.; Zhang, W.H.; Lin, X.Y. Study on the impact of energy poverty on energy efficiency of construction industry: Mediating role of energy consumption structure. Front. Energy Res. 2021, 9, 760895. [CrossRef]

38. Karkacier, O.; Goktolga, Z.G. Input-output analysis of energy use in agriculture. Energy Convers. Manag. 2005, 46, 1513-1521. [CrossRef]

39. Liu, H.T.; Xi, Y.M.; Guo, J.E.; Li, X. Energy embodied in the international trade of China: An energy input-output analysis. Energy Policy 2010, 38, 3957-3964. [CrossRef]

40. Lam, K.L.; Kenway, S.J.; Lane, J.L.; Islam, K.M.N.; de Berc, R.B. Energy intensity and embodied energy flow in Australia: An input-output analysis. J. Clean. Prod. 2019, 226, 357-368. [CrossRef] 
41. Li, Z.; Pan, L.Y.; Fu, F.; Liu, P.; Ma, L.W.; Arnorelli, A. China's regional disparities in energy consumption: An input-output analysis. Energy 2014, 78, 426-438. [CrossRef]

42. Tian, Z.Z.; Fang, D.L.; Chen, B. Three-scale input-output analysis for energy and water consumption in urban agglomeration. J. Clean. Prod. 2020, 268. [CrossRef]

43. Schultz, S. Approaches to identifying key sectors empirically by means of input-output analysis. J. Dev. Stud. 1977, 14, 77-96. [CrossRef]

44. Yang, Z.S.; Cai, J.M.; Dunford, M.; Webster, D. Rethinking of the relationship between agriculture and the "urban" economy in Beijing: An input-output approach. Technol. Econ. Dev. Econ. 2014, 20, 624-647. [CrossRef]

45. Xia, Y.; Guan, D.B.; Steenge, A.E.; Dietzenbacher, E.; Meng, J.; Tinoco, D.M. Assessing the economic impacts of IT service shutdown during the York flood of 2015 in the UK. Proc. R. Soc. A-Math. Phys. Eng. Sci. 2019, 475, 20180871. [CrossRef]

46. Ren, H.H.; Folmer, H.; Van der Vlist, A.J. What role does the real estate-construction sector play in China's regional economy? Ann. Reg. Sci. 2014, 52, 839-857. [CrossRef]

47. Song, Y.; Liu, C.L.; Langston, C. Linkage measures of the construction sector using the hypothetical extraction method. Constr Manag. Econ. 2006, 24, 579-589. [CrossRef]

48. Dietzenbacher, E.; van Burken, B.; Kondo, Y. Hypothetical extractions from a global perspective. Econ. Syst. Res. 2019, 31, 505-519. [CrossRef]

49. Temurshoev, U. Identifying optimal sector groupings with the hypothetical extraction method. J. Reg. Sci. 2010, 50, 872-890. [CrossRef]

50. Tokito, S.; Kagawa, S.; Hanaka, T. Hypothetical extraction, betweenness centrality, and supply chain complexity. Econ. Syst. Res. 2020, 32, 1-18. [CrossRef]

51. Guerra, A.I. A proposal to combine classical and hypothetical extraction input-output methods to identify key sectors for the production and distribution of electricity. Energy Effic. 2014, 7, 1053-1066. [CrossRef]

52. He, K.H.; Mi, Z.F.; Chen, L.; Coffman, D.; Liang, S. Critical transmission sectors in embodied atmospheric mercury emission network in China. J. Ind. Ecol. 2021, 25, 1644-1656. [CrossRef]

53. Sajid, M.J.; Li, X.C.; Cao, Q.R. Demand and supply-side carbon linkages of Turkish economy using hypothetical extraction method. J. Clean. Prod. 2019, 228, 264-275. [CrossRef]

54. Ali, Y. Measuring $\mathrm{CO}_{2}$ emission linkages with the hypothetical extraction method (HEM). Ecol. Ind. 2015, 54, 171-183. [CrossRef]

55. Zhang, J.J.; Yu, B.Y.; Cai, J.W.; Wei, Y.M. Impacts of household income change on $\mathrm{CO}_{2}$ emissions: An empirical analysis of China. J. Clean. Prod. 2017, 157, 190-200. [CrossRef]

56. Wang, Y.; Wang, W.Q.; Mao, G.Z.; Cai, H.; Zuo, J.; Wang, L.L.; Zhao, P. Industrial $\mathrm{CO}_{2}$ emissions in China based on the hypothetical extraction method: Linkage analysis. Energy Policy 2013, 62, 1238-1244. [CrossRef]

57. Guerra, A.I.; Sancho, F. Measuring energy linkages with the hypothetical extraction method: An application to Spain. Energy Econ. 2010, 32, 831-837. [CrossRef]

58. Deng, G.Y.; Wang, L.; Xu, X.Y. Linkage effect of virtual water trade in China's industrial products-based on generalized hypothetical extraction method. Ecol. Ind. 2018, 93, 1302-1310. [CrossRef]

59. Duarte, R.; Sanchez-Choliz, J.; Bielsa, J. Water use in the Spanish economy: An input-output approach. Ecol. Econ. 2002, 43, 71-85. [CrossRef]

60. Huang, H.P.; Li, X.S.; Cao, L.H.; Jia, D.D.; Zhang, J.L.; Wang, C.Y.; Han, Y.P. Inter-sectoral linkage and external trade analysis for virtual water and embodied carbon emissions in China. Water 2018, 10, 1664. [CrossRef]

61. Du, H.B.; Chen, Z.N.; Peng, B.B.; Southworth, F.; Ma, S.F.; Wang, Y. What drives $\mathrm{CO}_{2}$ emissions from the transport sector? A linkage analysis. Energy 2019, 175, 195-204. [CrossRef]

62. Wang, Y.Y.; Lei, Y.L.; Fan, F.Y.; Li, L.; Liu, L.N.; Wang, H.T. Inter-provincial sectoral embodied $\mathrm{CO}_{2}$ net-transfer analysis in China based on hypothetical extraction method and complex network analysis. Sci. Total Environ. 2021, 786, 147211. [CrossRef] [PubMed]

63. Sajid, M.J. Inter-sectoral carbon ties and final demand in a high climate risk country: The case of Pakistan. J. Clean. Prod. 2020, 269, 122254. [CrossRef]

64. Zhao, Y.H.; Zhang, Z.H.; Wang, S.; Zhang, Y.F.; Liu, Y. Linkage analysis of sectoral $\mathrm{CO}_{2}$ emissions based on the hypothetical extraction method in South Africa. J. Clean. Prod. 2015, 103, 916-924. [CrossRef]

65. Liao, H.; Andrade, C.; Lumbreras, J.; Tian, J. $\mathrm{CO}_{2}$ emissions in Beijing: Sectoral linkages and demand drivers. J. Clean. Prod. 2017, 166, 395-407. [CrossRef]

66. Georgescu-Roegen, N. The Entropy Law and the Economic Process; Harvard University Press: Cambridge, MA, USA, 1971.

67. Georgescu-Roegen, N. Energy analysis and economic valuation. South. Econ. J. 1979, 45, 1023-1058. [CrossRef] 